\title{
Does interdisciplinary research require interdisciplinary education?
}

\author{
by Jay A. Anderson ${ }^{1}$
}

\begin{abstract}
This paper presents an alternative view to some of the ideas put forth in The Forestry Chronicle (Vol. 81, No. 3) by arguing for a disciplinary approach to graduate-level education. There appears to be a diverging dichotomy between the educational requirements of forest managers and forest researchers. Forest managers today are barraged by an increasingly broad set of problems, and therefore likely benefit from an interdisciplinary education at the undergraduate level. In stark contrast to this generality, modern forest researchers solve problems so intricate and complicated that often only those specialists on the frontier of an academic discipline can contribute-which is why graduate-level curricula should, for the most part, remain disciplinary.
\end{abstract}

Key words: forest management, forest research, undergraduate-level curricula, graduate-level curricula, disciplinarity

\section{RÉSUMÉ}

Cet article présente une vision alternative de certaines idées mises de l'avant dans Le Forestry Chronicle (Vol. 81, No. 3) en soutenant une approche par discipline en matière de formation supérieure. Il semble y avoir une dichotomie divergente entre les besoins en matière de formation des aménagistes et des chercheurs en foresterie. Les aménagistes forestiers actuels font face à un ensemble de plus en plus vaste de problèmes et en conséquence, pourraient bénéficier d'une formation interdisciplinaire au niveau des études universitaires. Tout à fait à l'opposé de cette généralité, les chercheurs modernes en foresterie résolvent des problèmes tellement intriqués et compliqués que, souvent, ce sont seulement les spécialistes des limites du champ d'une spécialité académique qui peuvent apporter une contribution - ce pourquoi les programmes d'études supérieures devraient, en majeure partie, demeurer par discipline.

Mots clés : aménagement forestier, recherche forestière, programmes d'études universitaires, études interdisciplinaires

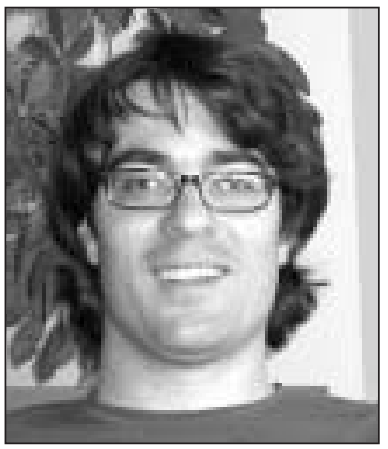

Jay A. Anderson

\section{Introduction}

Where there is much desire to learn, there of necessity will be much arguing, much writing, many opinions, for opinion in good men is but knowledge in the making. JOHN MILTON

I enjoyed the theme of "international perspectives on interdisciplinary research" in The Forestry Chronicle (Vol. 81, No. 3). I became concerned, however, when discussion strayed from promoting interdisciplinary education at the undergraduate level, which I support, to promoting interdisciplinary education at the graduate level, which I question.

The connection between interdisciplinary education and interdisciplinary research was explicitly expressed in the statement that "[a]t graduate school, and in the early stages of a graduate career, the focus on depth rather than breadth is training people to become excellent scientists within their own field of interest, but is not preparing them for the type of research that is increasingly called for" (Innes 2005). As a doctoral student, part of me agrees with this call for more flexible curricula, especially when I feel overwhelmed by the numerous courses and comprehensive exams necessary to become a specialist in forest economics. But my intuitions (and, more importantly, my professors) suggest that an interdisciplinary education is unwise for a career in research. So I toil onwards in the belief that as a specialist, I will one day have a sufficient level of expertise to contribute in knowledge making. And as justification for this decision to specialize in one discipline, I will now offer a view as to why interdisciplinary education may not be required for interdisciplinary research.

A major problem with interdisciplinary education at the graduate level is that as knowledge grows, the rigorous study required to acquire depth leaves inadequate time to acquire breadth. It is therefore fortunate that breadth can be achieved by forming research groups of specialists from different disciplines (i.e., interdisciplinary research), thus freeing students to focus on their disciplines, and returning us to the important question of how much depth we should require in our university curricula. To address this question of depth versus breadth, I will first suggest why forest managers require different training than forest researchers; I will then highlight my views on interdisciplinary research; and finally, I will conclude by suggesting a compromise in this important debate of whether to educate researchers as generalists or specialists.

\section{Forest Managers Are Not Forest Researchers}

Having practised as an industry forester for six years prior to returning to graduate school, my overall impression is that a technical and/or undergraduate education is currently ade-

\footnotetext{
${ }_{1}$ PhD Student, Forest Economics, Department of Rural Economy, 515 GSB, University of Alberta, Edmonton, Alberta T6G 2H1. E-mail: jaya@ualberta.ca
} 
quate for most forest management roles. Yet there is always room for improvement, and hence I believe that undergraduate-level curricula could be more broadly based-especially with respect to the social sciences.

However, foresters are not researchers, and there is a difference between the training required for quality forest management versus quality forest research. Forest management requires making decisions with ramifications on everything from a meadow vole to a school teacher, and thus requires a wide breadth of knowledge. Forest research, on the other hand, requires solutions to problems so intricate and complicated that only those on the frontier of their discipline will likely make a contribution, which is why I believe that graduate-level curricula should, for the most part, remain disciplinary.

\section{Interdisciplinary Research by Specialists}

In an editorial in The Forestry Chronicle, Vic Adamowicz (2004), former program leader of the Sustainable Forest Management Network, suggested that the success of interdisciplinary research is based on "the comparative advantage associated with different skills being brought to the team by different members." Interdisciplinary research acknowledges that one person cannot know everything, and that the problems facing our forests are of such a complex nature that understanding will likely come from teams made up of specialists from different disciplines.

Allow me to emphasize these first points with an example. Consider intensive forest management in the boreal forest, which is for the most part conducted by foresters and forest technologists. The multidisciplinary training and field experience of these forest managers help them to solve many significant problems. They are, however, having difficulty solving the problem of inter-specific competition within plantations. Some forest managers use herbicide to keep grasses and shrubs under control, but the small time-window available to apply the chemicals greatly reduces its applicability, and thus its effectiveness.

Now suppose, hypothetically, that I am the program leader of an interdisciplinary research network, and these forest managers have asked me to initiate research on tree biotechnology, since herbicide-resistant trees have a much longer herbicide application window. Would I set up a team of multidisciplinary researchers who each know a little about a whole lot of things? Not likely. Topics as challenging as biotechnology require the academic rigor of specialists. And since biotechnology touches on so many issues, I would select a diverse team of well trained researchers, including sociologists, molecular biologists, political scientists, tree physiologists, economists, geneticists, et cetera.

\section{Forester-Scientist: The Specialized Generalist}

In the above biotechnology problem, forest managers first communicate the problem to researchers, who then work together to find solutions. How well these interactions between managers and researchers actually occur is debatable. Indeed, the separation between "the bush" and "the ivory towers" might be a problem, particularly if there is little incentive for researchers to work with forest managers. A means for minimizing this interaction problem would be for more researchers to do as I have, and begin their disciplinary graduate school training upon the interdisciplinary base of an undergraduate forestry degree. This way, not only is the forester-scientist aware of many of the problems forest managers face, but they also speak the same "lingo," thus making them better at understanding new problems as they arise. We already see this model in other professions, such as medicine, where joint $\mathrm{MD}-\mathrm{PhD}$ programs are common. In essence, these researchers would be a compromise in the generalist versus specialist debate, since a forester-scientist has the best of both worlds: the interdisciplinary education of a forestry program combined with the academic rigor of a scientific discipline.

There could be other advantages to encouraging the specialized and high-tech side of graduate studies to undergraduate forestry students. Currently, forestry programs are struggling with low enrollment (Luckert 2004), which might be based on public perception that forestry is a low-tech and stagnant profession. If more emphasis was placed on opportunities that exist for forestry graduates in specialized and high-tech graduate-level research, forestry programs might attract more undergraduate students.

\section{The Market for Forest Researchers}

In the academic environment of "publish or perish," nowhere is the correlation between expertise and research success more known than in universities and research institutions. Here, advocates of interdisciplinary education may feel that "the conservative nature of the academic system" results in a job market where " $[\mathrm{s}]$ cientists who are genuinely interdisciplinary may have difficulties finding employment" (Innes 2005). Yet one could also view this phenomenon as an indication of value, such that within the marketplace of highlyqualified researchers, it is possible that fewer generalists are hired because they are less successful than specialists in explaining our increasingly complicated world. Such preferences for hiring specialists is not surprising within the current environment of interdisciplinary research - where breadth and depth are achieved through the collaborative efforts of research teams comprised of specialists from different disciplines - which suggests that for interdisciplinary research to remain successful, universities should protect disciplinarity within graduate-level curricula.

\section{Acknowledgements}

The opinions stated in this paper are solely those of the author. For participating in a lively discussion that helped form many of these opinions, thanks are due to Vic Adamowicz, Peter Boxall and Marty Luckert. Additional editorial support was provided by Marty Luckert, for which I am also grateful. Funding for this work was provided by the University of Alberta PhD Scholarship and the University of Alberta Department of Rural Economy. This paper is dedicated to the memory of my friend and classmate, Brett Cortus.

\section{References}

Adamowicz, W.L. 2004. "Big science": Is the move towards interdisciplinary research teams in forest management a good thing? For. Chron. 80(5): 542-546.

Innes, J.L. 2005. Multidisciplinarity, interdisciplinarity and training in forestry and forest research. For. Chron. 81(3): 324-329.

Luckert, M.K. 2004. Why are enrollments in Canadian forestry programs declining? For. Chron. 80(2): 209-214. 